\title{
Tereza Teofilová
}

Department of Speech and Language Therapy and Communication Ability Studies, Institute of Special Education Studies, Faculty of Education, Palacký University in Olomouc (D) https://orcid.org/0000-0002-8875-5621

Jana Mironova TABachová

Department of Speech and Language Therapy and Communication Ability Studies, Institute of Special Education Studies, Faculty of Education, Palacký University in Olomouc

(D) https://orcid.org/0000-0001-5322-5260

Kateřina VitásKová

Department of Speech and Language Therapy and Communication Ability Studies, Institute of Special Education Studies, Faculty of Education, Palacký University in Olomouc (D) https://orcid.org/0000-0002-6607-0808

\section{Development of communication skills in a bilingual child of Czech-Vietnamese origin in preschool age from the viewpoint of speech pathology}

AвsтRACт: The article describes the experience of conducting speech therapy with a bilingual (sequential bilingualism) boy of Vietnamese origin in preschool age. The authors identify main differences between Czech and Vietnamese, and also point to specific linguistic interference occurring in the case of a Vietnamese-speaking person learning Czech. The aim of the authors is to describe the development of the boy's language skills and the possibilities for his language development in kindergarten and during preparatory classes for school education. Speech therapy aimed at supporting the development of communication skills lasted seven months and involved the inclusion of multi-sensory games and activities to support various language levels. Particular emphasis was placed on auditory differentiation (including vowel quantity), auditory memory and phonological awareness (including the division of words into syllables and the analysis and synthesis of sounds).

KEYWORDS: speech therapy, special education, preschool age, communication skills, bilingualism, Vietnamese language, Czech language

Rozwój umiejętności komunikacyjnych dwujęzycznego dziecka pochodzenia czesko-wietnamskiego w wieku przedszkolnym z perspektywy patologii mowy

Streszczenie: W artykule przedstawiono doświadczenia w prowadzeniu terapii logopedycznej z bilingwalnym (dwujęzyczność sekwencyjna) chłopcem pochodzenia wietnamskiego w wieku przedszkolnym. Autorzy identyfikują główne różnice między językiem czeskim i wietnamskim, a także wskazują na konkretne interferencje językowe występujące w przypadku osoby wietnamskojęzycznej uczącej się czeskiego. Celem autorów jest opis rozwoju umiejętności językowych wspomnianego chłopca oraz możliwości jego rozwoju językowego w przedszkolu oraz w trakcie zajęć przy- 
gotowawczych do edukacji szkolnej. Terapia logopedyczna ukierunkowana na wspieranie rozwoju umiejętności komunikacyjnych trwała siedem miesięcy i obejmowała włączenie gier i zabaw oddziałujących na wiele zmysłów, tak aby wspierać różne poziomy językowe. Szczególny nacisk był położony na rozróżnienie (m.in. ilości samogłosek), pamięć słuchową oraz świadomość fonologiczną (m.in. podział słowa na sylaby i analizę oraz syntezę dźwięków).

SŁoWA KLUCzowE: terapia logopedyczna, pedagogika specjalna, wiek przedszkolny, umiejętności komunikacyjne, dwujęzyczność, język wietnamski, język czeski

There is a clear difference between the Vietnamese language and the Czech language. For example, according to Ivo Vasiljev (2010), this is probably the greatest difference between existing human languages. To learn Czech for a Vietnamese person is just as difficult as it is for a Czech person to learn Vietnamese, although both experience different linguistic difficulties along the way (Vasiljev, 2010). In learning Czech, the most challenging for Vietnamese people is to learn pronunciation and grammar, maybe because Vietnamese is an isolating language (meaning is determined by word order). Vietnamese uses single-syllable language units whose content is expressed by using one of the 6 tones. On the contrary, Czech is a fusional language (uses declension and conjugation) and includes both single and multi-syllable words (Komers \& Slezáková, 2010, pp. 250-252; Hájková, 2015). In terms of building of vocabulary, in Czech this process takes place by an accumulation of syllables or clustering of consonants, while in Vietnamese these changes in word order must be made within a single syllable by means of the socalled tones (Vasiljev, 2010). Vietnamese has a large vowel inventory containing 14 vowels of which 3 are diphthongs (Slavická, 2008). In the Vietnamese language, a diacritic must be applied to specify which tone should be used to pronounce each syllable. It should be noted that acute accents above vowels do not change their quantity because vowel length is not a distinguishing factor in Vietnamese (Kocourek \& Pechová, 2010).

TABLE 1. Graphical symbols in Vietnamese

\begin{tabular}{|l|l|l|l|}
\hline \multicolumn{1}{|c|}{ Identification } & \multicolumn{1}{|c|}{ Tone } & \multicolumn{1}{c|}{$\begin{array}{c}\text { Example } \\
\text { word }\end{array}$} & \multicolumn{1}{c|}{ Meaning } \\
\hline No diacritic & High flat & ma & ghost or spook \\
\hline Short diagonal line from left to right above the letter & Low falling & mà & which, who, etc. \\
\hline Short diagonal line from right to left above the letter & Rising & má & face or faces \\
\hline "Question mark" above the letter & Falling-rising & mả & grave \\
\hline “Tilde" above the letter & High interrupted & mã & knight in chess \\
\hline Dot below the letter & Low with stops & mạ & rice seedlings \\
\hline
\end{tabular}

Sou RCE: Modified according to Slavická, 2008; Vasiljev, 2010. 
As for the common features of the two languages, both Czech and Vietnamese use the Latin alphabet for writing (29 letters) but some consonant and vowel letters are read in a totally different way (Kocourek \& Pechová, 2010; Gjurová, 2011). The Latin alphabet started to be used in Vietnam thanks to Portuguese and French missionaries, who developed the local writing about 400 years ago in collaboration with Vietnamese scholars who turned to Christian faith. The missionaries were prevented from spreading Christianity due to a language barrier which they tried to overcome by learning the language of the local inhabitants. These efforts brought them to an idea to write down the pronunciation of Vietnamese in their native languages (Slavická, 2008; Vasiljev, 2010). Chinese characters had played a significant role in written communication in Vietnam for a period of 2000 years. Currently, Vietnamese people are unable to read them (Kocourek \& Pechová, 2010). Moreover, in Vietnam there are three major dialects spread around the northern, central and southern parts of the country (Slavická, 2008). The standard and official Vietnamese language is the so-called Hanoi dialect, which is the dialect spoken in North Vietnam (Slavická, 2008; Slówik, \& Tůmová, 2016, pp. 15-30). The linguistic differences and their common characteristics are examined by many linguists (Pham \& McLeod, 2019, pp. 2645-2670).

The difficulties of Vietnamese people who learn Czech stem particularly from phonological deviations including sound confusions because Vietnamese does not

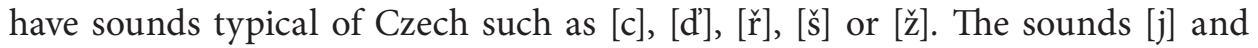
[r] are used only in Vietnamese dialects. Vietnamese people also have problems with pronouncing sounds that exist in Vietnamese but are used only in specific positions (Komers \& Slezáková, 2010, pp. 250-252). In modern Vietnamese there are 21 consonants in the initial position. Concerning the place of articulation and the way of production they resemble Czech consonants (Slavická, 2008). Their graphic form, phonetic transcription and pronunciation are shown in Table 2.

TABLE 2. Consonants in the initial position in modern Vietnamese

\begin{tabular}{|l|l|l|}
\hline \multicolumn{1}{|c|}{$\begin{array}{c}\text { Graphic } \\
\text { form }\end{array}$} & \multicolumn{1}{c|}{$\begin{array}{c}\text { Phonetic } \\
\text { transcription }\end{array}$} & \multicolumn{1}{c|}{ Pronunciation } \\
\hline $\mathrm{b}$ & {$[\mathrm{b}]$} & as the Czech [b] \\
\hline $\mathrm{m}$ & {$[\mathrm{m}]$} & identical to the pronunciation of $[\mathrm{m}]$ in Czech \\
\hline $\mathrm{v}$ & {$[\mathrm{v}]$} & as the Czech [v], in the southern dialect as [j] \\
\hline $\mathrm{ph}$ & {$[\mathrm{f}]$} & as the Czech [f] \\
\hline $\mathrm{d}$, gi & {$[\mathrm{z}]$} & $\begin{array}{l}\text { as the Czech }[\mathrm{z}] \text { in the northern dialect, in the central } \\
\text { and southern dialect as [j] }\end{array}$ \\
\hline d & {$[\mathrm{d}]$} & as the Czech [d] \\
\hline
\end{tabular}


T. Teofilová, J. Mironova Tabachová, K. Vitásková: Development of communication...

Table 2 (cont.)

\begin{tabular}{|c|c|c|}
\hline 1 & {$[1]$} & $\begin{array}{l}\text { as the Czech [1], in the northern Vietnamese dialect } \\
\text { in the Hanoi area substituted by [n] }\end{array}$ \\
\hline $\mathrm{n}$ & [n] & as the Czech [n] \\
\hline $\mathrm{t}$ & {$[\mathrm{t}]$} & as the Czech $[\mathrm{t}]$ \\
\hline th & {$\left[\mathrm{t}^{\prime}\right]$} & with aspiration \\
\hline $\mathrm{x}$ & {$[\mathrm{s}]$} & as the Czech [s] \\
\hline $\mathrm{r}$ & [z] & $\begin{array}{l}\text { only in the central dialect, in the northern dialect similar } \\
\text { to the Czech }[\mathrm{z}] \text {, in the southern dialect as }[\mathrm{z}] \text { or }[\mathrm{z}]\end{array}$ \\
\hline s & [s] & $\begin{array}{l}\text { only in the central and southern dialect, in the northern } \\
\text { dialect as [s] }\end{array}$ \\
\hline $\operatorname{tr}$ & [t] & $\begin{array}{l}\text { as the Czech [č }] \text { in the central and southern dialect, } \\
{[\mathfrak{t}] \text { in the northern Vietnamese dialect }}\end{array}$ \\
\hline ch & {$[c]$} & $\begin{array}{l}\text { in the central and southern dialect as }[\mathrm{c}] \text {, in the northern } \\
\text { dialect similar to }[\mathrm{t}]\end{array}$ \\
\hline $\mathrm{nh}$ & [n] & same as the Czech [ň] \\
\hline $\mathrm{c}, \mathrm{k}, \mathrm{q}$ & {$[\mathrm{k}]$} & as the Czech [k] \\
\hline g, gh & [४] & similar to the Czech [g] \\
\hline ng, ngh & [n] & as the Czech [n] \\
\hline $\mathrm{kh}$ & {$[\mathrm{x}]$} & as the Czech [ch] \\
\hline $\mathrm{h}$ & {$[\mathrm{h}]$} & as the Czech [h] \\
\hline
\end{tabular}

SOURCE: Slavická, 2008.

A sound that can cause problems to Vietnamese speakers is [p], which does not occur in the initial position in Vietnamese and is eventually substituted with [b] (for example bráce instead of práce) (Komers \& Slezáková, 2010, pp. 250-252). Also, Vietnamese has a limited number of consonants in the final position. They include the following consonants: $[\mathrm{m}],[\mathrm{n}],[\mathrm{n}],[\mathrm{p}],[\mathrm{t}]$ and $[\mathrm{k}]$ (Pham \& McLeod, 2019, pp. 2645-2670). Therefore, some Czech sounds are difficult for Vietnamese to pronounce, which results in a substitution with a common Vietnamese consonant (for example/tisit/ instead of /tisíc/) or they completely eliminate the final consonant (/rada/instead of / radar/). They also face problems with the pronunciation of consonant clusters, which results in a reduction the number of consonants to minimum (for example /neska/ instead of /dneska/), insertion of a Vietnamese vowel or metathesis, i.e. transposition of sounds (for example $/ v k l /$ instead of $/ v l k /$ ). Another common phenomenon is a reduced ability to distinguish the quantity of vowels in both spoken and written form (Komers \& Slezáková, 2010, pp. 250-252; Slówik \& Tůmová, 2016). Jiři Kocourek and Eva Pechová (2010) add that Vietnamese people have problems with differentiating the sound [1] and [n], 
voiceless and voiced sounds and oppositions $[s]$ and $[\check{s}],[c]$ and $[\check{c}],[r]$ and [ř $]$, [d] and [d]. Also, they cannot distinguish syllables in a word or perform a syllable analysis. This results for example in shortening or elimination of sounds. Morphological or grammatical categories (gender, declension, conjugation) do not exist in Vietnamese. It is even impossible to identify whether words are nouns, adjectives or verbs (Kocourek \& Pechová, 2010) Words gain grammatical properties only in their context. More experienced Vietnamese users of Czech may have minor problems with case endings (for example in prepositional phrases). Less talented speakers even reduce verbs to a single form or a limited number of forms.

While in the Czech Republic speech-language pathology has had a long tradition (for example Viktor Lechta, 2007, pp. 29-35), in Vietnam it is only beginning to develop. For example, it was only recently that developmental language disorders among Vietnamese preschool children started to be analysed. The first comprehensive study on speech acquisition in North Vietnam was conducted by Ben Pham and Sharynne McLeod (2019, pp. 2645-2670). The research included a total of 195 pupils aged 2 to 5 years with Vietnamese as L1. The results show the level of acquired consonants, liquids, sounds and tones in each development period. The following consonants turned out to be the most difficult to learn: $[\mathrm{n}],[\mathrm{s}],[\mathrm{z}]$ and $[\mathrm{x}]$ (for pronunciation see above). The results of the research have provided preliminary data to support the emerging profession of speech-language pathology in Vietnam. The professional experience of the first Vietnamese speech-language therapists is increasing and so is the awareness of Vietnamese people about the provision of speech-language therapy (Atherton, Davidson \& McAllister, 2019). According to B. Pham and S. McLeod (2016, pp. 122-134), speech-language therapists have to be aware of the differences between Vietnamese dialects. Based on the knowledge of the characteristics of these dialects, speech-language therapy can be tailored to the needs of every Vietnamese speaking client.

A diagnostic tool used for the determination of specific language impairment in bilingual children is based on non-word repetition (Kapalková \& Tokárová, 2017, pp. 56-60). However, insufficient attention has so far been paid to Asian tone languages. A study by Giang Pham, Kristine T. Dinh, Quynh Dam and Kerry D. Ebert (2018, pp. 1311-1326) examined whether task properties really have a universal character in the detection of developmental language disorders. The research included a total of 59 bilingual Vietnamese-English children with Vietnamese as L1. The items were presented by a trained research assistant fluent in Vietnamese. The findings of the study are consistent with the results of research studies in similar languages (for example Cantonese). The participants were most accurate in repeating tones, which may have been related to the inclusion of a limited number of tones. The research group was also significantly more accurate in repeating consonants than vowels, which may again have been related 
to the low number of stimuli. The researchers suggest that another explanation could be the significant role of vowels that make up the syllable core and determine its tone. The authors of the research believe that the results will facilitate the work with bilingual children who learn Vietnamese as L1 or L2. A comparison of NWR among bilingual children in both languages should contribute to a broader understanding of how phonological memory relates to language exposure (Pham, Dinh, Dam \& Ebert, 2018, pp. 1311-1326).

Kateřina Vitásková (2010) comments on the situation of migrant pupils or students who have already settled in the new country or are preparing for inclusion in the educational or occupational process. Although these individuals are not considered people with disrupted communication ability, this group should be provided with individualized assessment and therapy by a professional speech-language therapist taking cultural differences into account. The interest of immigrants in speech-language therapy services is increasing (Vitásková, 2016).

The information above may evoke the following question: How should a speech-language therapist proceed in the examination of a bilingual child without knowledge of the child's mother tongue. In an ideal case, the therapist should perform the examination in both languages to prevent distorted results as a result of testing in the weaker language. However, in speech-language therapy this appears to be an impossible task. Standards the assess the language level for bilingual children are often unavailable and standardized tests for the monolingual population do not consider the specificities of bilingualism (Štefánik, 2010; Kapalková \& Palugyayová, 2016, pp. 45-50).

In diagnosing bilingual children, speech-language therapists can follow the instructions published by the American Speech-Language-Hearing Association (ASHA). The ASHA recommends speech-language therapists (Paul \& Norbury, 2012) to test children in their mother tongue, examine their oral motor skills, perform an indicative auditory examination, perform a non-verbal examination, perform an interview with parents assisted by an interpreter and acquire information about the client's language and culture. During the examination the general key indicators include the length and intensity of contact with the majority language (Kapalková \& Palugyayová, 2016, pp. 45-50). The data obtained in the diagnostic process should be followed by a detailed analysis and interpretation in order to design an appropriate therapy. In the case that the client's disrupted communication ability affects both languages, therapy should preferably be conducted in both languages. As has already been indicated, there are only few speech-language therapists who provide speech-language intervention in multiple languages. However, if therapy is conducted in the child's weaker language, many language skills are stimulated that are also reflected in the other language (Kapalková \& Palugyayová, 2016, pp. 45-50). 
According to the amendment to the Education Act, children in the Czech Republic with a different mother tongue are entitled to support measures including teaching Czech as a second language (Titěrová et al., 2019).

Tereza Linhartová and Barbora Loudová Straczynská (2018) summarize the levels of support measures in the context of inclusive education and provide a list of measures that children are entitled to. They specify that children with a different mother tongue are usually classified in level two or three support (see Table 3).

TABLE 3. The children with various mother tongues and levels of support

\begin{tabular}{|c|c|}
\hline \multirow[t]{2}{*}{ Level 1} & $\begin{array}{l}\text { The children with an advanced level of the Czech language who require more } \\
\text { intensive support in language development }\end{array}$ \\
\hline & Requirements: minor adjustments to the organization, methods and approach \\
\hline \multirow[b]{2}{*}{ Level 2} & The children with insufficient knowledge of the Czech language \\
\hline & $\begin{array}{l}\text { Requirements: individual education plan, special teaching aids, adjustments } \\
\text { to the organization, content and methods, } 40 \times 15 \text { minutes per week of Czech } \\
\text { as a second language (CSL) - maximum of } 80 \text { hours }\end{array}$ \\
\hline \multirow[b]{2}{*}{ Level 3} & The children with no knowledge of the language of instruction \\
\hline & $\begin{array}{l}\text { Requirements: individual education plan, special textbooks and teaching aids, } \\
\text { assistant teacher, assistance by another teaching staff member of } 0.5 \mathrm{FTE} \text {, } \\
4 \times 15 \text { minutes per week of CSL - maximum of } 110 \text { hours }\end{array}$ \\
\hline Level 4-5 & $\begin{array}{l}\text { The children with a different mother tongue in case of another (for example health) } \\
\text { disability }\end{array}$ \\
\hline
\end{tabular}

SOU RCE: Linhartová \& Loudová Straczynská, 2018.

\section{Description of the research study - objectives and methodology}

The main objective of the present study was to map the development of communication skills of a bilingual Vietnamese preschool boy and to acquire information about the conditions for development the boy had in the kindergarten and preparatory class. This is a partial outcome of the author's master's diploma thesis (Teofilová, 2020). For a quantitative analysis of the development of communication skills a diagnostic battery was used focusing particularly on phonology, vocabulary and grammar.In November 2018, the main author of the paper was asked by a kindergarten teacher, who sought for ways of helping a five-year-old successively bilingual boy. The boy is Vietnamese and faced major communication problems. The teacher provided the boy with extra care in her free time 
but soon realized the boy needed professional help. Therefore, she turned to the main author of the text and asked her for a regular speech-language intervention. After the first meeting with the child's father, a long-term cooperation plan was agreed. The main author worked with the boy 1-2 times a week, either directly in the boy's home, where the session was always enthusiastically joined by the boy's older sister or in the morning or afternoon in the kindergarten.

The boy's language development and behaviour among classmates were discussed with the teacher on a regular basis. To make the intervention comprehensive as much as possible, we linked it with the usual kindergarten activities. In performing the Assessment and intervention, the main author used the knowledge and skills she had acquired during her undergraduate study and practice. In terms of working with foreigners who require a specific approach she was inspired by relevant literature and materials freely available on the internet. In August 2019 the main author contacted a local clinical speech-language therapist and asked her for supervision and consultation of the boy's language development. The boy's father gave a written informed consent to representation in matters relating to speech-language therapy.

\section{Quantitative research methods}

After a long-term speech-language intervention aimed at a bilingual Vietnamese child we compared the results of the Language Development Diagnostic Tests by Seidlová Málková and Smolík (2014). The following two research questions were formulated:

Research question 1: "What changes were observed in the child after the sevenmonth speech-language intervention in phonological subtests?"

Research question 2: "What changes were observed in the child after the seven-month speech-language intervention in lexical and grammatical subtests?"

For a clearer representation of the changes in the subtests, the following hypotheses were defined:

- H1: After the seven-month speech-language intervention the child scored a higher number of points in the phonemic awareness subtest.

- H2: After the seven-month speech-language intervention the child was able to complete the rapid naming subtest in a shorter period of time.

- H3: After the seven-month speech-language intervention the child scored a higher number of points in the phonological memory subtest.

- H4: After the seven-month speech-language intervention the child scored a higher number of points in the vocabulary subtest.

- H5: After the seven-month speech-language intervention the child scores a higher number of points in the implicit grammar knowledge subtest. 
- H6: After the seven-month speech-language intervention the child scored a higher number of points in the metalanguage grammar knowledge subtest.

To assess and evaluate the boy's language development, the present research used the psychodiagnostic test designed by Gabriela Seidlová Málková and Filip Smolík (2014). This is a freely available test battery for use by the general scientific community. It is important for each user to observe all instructions in the battery manual during administration and interpretation. During the preparation of the test material, it turned out that most of the tasks were rather easy for children. As a result, it is more sensitive to the performance of relatively weaker children. This diagnostic material was used especially because of its capacity of discrimination of below-average results which were anticipated for the sample. The test contains a total of ten subtests divided into two main parts. Some of the subtests are further divided into two blocks addressed to younger (3-4 years old) and older children. Regarding the fact that all of the items of the diagnostic material have been used, we believe it is important to provide an overview of all ten subtests (Seidlová Málková \& Smolík, 2014):

Five tests to assess the processing of phonological information

- Three subtests assess phonemic awareness: recognition of syllables, blending of syllables, recognition of sounds in pseudo-words;

- One subtest assesses phonological memory: rapid automatized naming (RAN);

- One subtest assesses rapid naming: repetition of pseudo-words.

Five tests to assess vocabulary, language comprehension and grammar

- One subtest assesses vocabulary knowledge: Vocabulary;

- Two subtests assess implicit knowledge of grammar: morphology, understanding of grammar;

- Two subtests assess metalanguage knowledge of grammatical rules: assessment of grammatical correctness, correcting sentences;

\section{Results}

This section provides a brief description of the results of the subtests, for the purpose of this article based only on the qualitative verbal comments. Regarding the age of the bilingual boy, the testing blocks for older children were used. 


\section{Recognition of syllables}

\section{Qualitative assessment}

Assessment April 2019: In the first block, the boy made three mistakes in syllables starting with the sound [m] (motýl-misa/moře; meloun-medvěd/moucha)

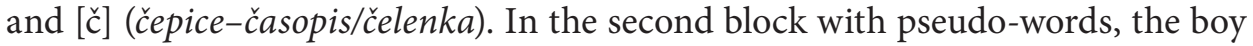
scored zero points and did not even attempt to solve the task in this block.

Assessment March 2020: In the first block, the boy made only one mistake in the syllable starting with the sound [s] (sešit-salám/sekera). In the second block, the boy said all words correctly. He also noted that the task was easy.

\section{Blending of syllables}

\section{Qualitative assessment}

Assessment April 2019: In the first block, the boy made 5 mistakes (out of 16). He made mistakes especially in the quality of sounds (for example /mleko/ instead of $/ \mathrm{mléko} /$ ) and in one case a substitution was made ((letopil/ instead of Inetopýr/). In the second block with pseudo-words the boy made 6 mistakes (out of 8). The researchers observed elimination, substitution (for example /salenda/ instead of /čálenda/) and non-observance of sound quality. In all of the cases replies were given and no words had to be repeated. The boy preserved the syllable structure of the words.

Assessment March 2020: In the first block the boy made 2 mistakes (out of 16). The mistakes related to sound quantity (/žaba/ instead of (žába/ and /mochomurka/ instead of /mochomurka/), which improved the test score. In the second block the boy made 5 mistakes (out of 8 ). The boy made one substitution and one metathesis (/bravanek/ instead of /bavránek/); problems persisted in sound quantity. However, the words were close to the correct answer. In all of the cases replies were given and no words had to be repeated. The syllable structure was retained in all of the words.

\section{Recognition of sounds in pseudo-words}

\section{Qualitative assessment}

Assessment April 2019: The boy repeated all of the words. Most of the mistakes were made in words starting with the sound [l] and [k] (in both cases only 1 point of 7 was scored for each sound) and in words starting with the sound [m] and [b] (3 points scored in both cases). The highest number of points was scored in words starting with the consonant [s] (6 points). 
Assessment March 2020: The boy repeated all of the words. The boy isolated and defined the first sounds perfectly without delay. A confusion of sounds occurred only in one word in the final position.

\section{Rapid automatized naming}

\section{Qualitative assessment}

Assessment April 2019: Only one block was used in the subtest. In one case the boy repeated himself in the penultimate line. In the naming activity he made a total of six mistakes; he paused and made a prolonged /eh/ sound. None of the pictures were skipped.

Assessment March 2020: Only one block was used in the subtest. The naming procedure was much faster. The boy made the same number of mistakes as is April 2019. He paused and clicked his tongue or made a prolonged /eh/ sound. None of the pictures were skipped.

\section{Repetition of pseudo-words}

\section{Qualitative assessment}

Assessment April 2019: The boy completed the subtest without the words having to be repeated. The boy made the following mistakes: metathesis (for example /nefelot/ instead of /lefenot/), elimination of sounds in the final position (for example /zoví/ instead of /zovík/) and consonant clusters (for example /hamilon/ instead of /hamikaron/), substitution in the initial position (for example /becice/ instead of /pečice/). The boy also made mistakes in the quantity of sounds (for example /sakuhněl/ instead of /sákuhněl/).

Assessment March 2020: The boy completed the tasks without the words having to be repeated. In two words the boy made a substitution (/namina/ instead of /namila/, /kešipamte/ instead of /klešipamke/) but pronunciation improved considerably. Sound quantity was preserved in this test.

\section{Vocabulary}

\section{Qualitative assessment}

Assessment April 2019: After training the boy immediately understood the instruction. He sometimes repeated the word for himself and then showed it. A total of 6 words had to be repeated. He made mistakes in the identification of the following words: mince, krajíc, jezero, poušt', sako, šunka, regál, glóbus, plešatý. 
Assessment March 2020: The boy completed the tasks without the words having to be repeated but did not achieve the maximum number of points. The following words were identified incorrectly: krajíc, dobytek, sako, regál, plešatý.

\section{Morphology}

\section{Qualitative assessment}

Assessment April 2019: The boy achieved 5 points in this subtest (total of 30). In two cases the boy did not want to answer. In the plural making test the boy had a tendency to change the noun to diminutives in singular or plural (for example /stolešky/ instead of /stoly/ or /ptáček/ instead of /ptáci/) and vice versa (/koška/ instead of / kočičky/). The activities were identified with about $50 \%$ success rate. When the boy was supposed to make the past tense, he made the present tense. In gender inflection some of the professions were repeated in the same form (for example/doktorka/-/doktorka/), sometimes a verb was derived (/uklízečka//uklizí/) or a derived noun was used (/zahradník/-/zahládky/). In the past tense and gender inflection tasks the boy scored zero points. In the block focusing on making correct forms of words with prepositions the boy did not give any correct answer (he used the first case after the preposition, for example $u$ /věšák/, or an incorrect form, for example /v knihovni/).

Assessment March 2020: The boy gave an answer in all tasks. He significantly improved in the use of the past tense and in gender inflection of professions. In the first block focusing on making plurals the boy made similar mistakes (for example /balónky/ instead of /balóny/, /kočky/ instead of /kočičky/). In making the past tense we observed one mistake (/stavil/ instead of/stavěl/). The boy scored the lowest number of points in the last block. However, contrary to the previous diagnostic test this time he scored 2 points (/u věšáku/, /před šuplíkem/). Incorrectly formed words were declined in the first case (for example /na stůl/ instead of /na stole/, /před televize/ instead of /před televizí/).

\section{Understanding of grammar}

\section{Qualitative assessment}

Assessment April 2019: In three cases, the instruction had to be repeated for the boy to identify the correct picture.

Assessment March 2020: The boy responded when asked for the first time. He scored the full number of points. 


\section{Assessment of grammatical correctness}

\section{Qualitative assessment}

Assessment April 2019: One sentence had to be repeated. In all cases, the boy replied that the sentence was correct.

Assessment March 2020: Sentence repetition was not used. The boy laughed at incorrect sentences. Sometimes he suggested the correct answer, for example /paní vařila/ instead of /paní vařilo/. In March the boy made no mistakes.

\section{Correcting sentences}

\section{Qualitative assessment}

Assessment April 2019: In two cases, the boy did not respond even after the sentence had been repeated. All responses were incorrect. In one case he substituted the verb (/Myška papá/.); he did not correct the word order (/Soubek plasatko vede/); he did not make the correct form of the word using the correct case (for example /Holka opeka buštovi/); he left out the reflexive pronoun (/Klu(k) a holka hlají/) There were also various combinations of grammatical mistakes (/Máma a holčiška čeka na autobusu/.)

Assessment March 2020: There was no need to repeat the sentences. The boy did not reach the maximum number of points, but the corrected sentences were close to the correct answers. He even commented on one of the sentences: "Myška okusuje sýr, ne sýrem!" There were also some problems with an incorrect word order (/Soudek prasátko nese/.) Also, the boy made other grammatical mistakes (/Lupic sedí na koně/, /Kluk a holka hrajeme/, /Máma a holčička čekajou na autobus/).

\section{Answers to research questions and hypotheses in the quantitative part of the research}

The seven-month therapy resulted in an improvement in the phonological, lexical and grammatical subtests. This finding confirmed all of the hypotheses.

Research question No. 1: "What changes were observed in the child after the seven-month speech-language intervention in phonological subtests?"

H1: After the seven-month speech-language intervention the child scored a higher number of points in the phonemic awareness subtest. In the phonemic awareness subtests, the boy achieved a higher number of points. In Recognition of syllables he lost only one point and also completed the second more difficult block containing pseudo-words. In Blending of syllables, he maintained the struc- 
ture of the word but after the seven-month therapy he had problems with sound quantity and in the case of pseudo-words kept on making substitutions or metatheses. In Recognition of sounds in pseudo-words, which requires manipulation with the smallest phonological unit the boy achieved the full number of points.

$\mathrm{H} 2$ : After the seven-month speech-language intervention the child was able to complete the rapid naming subtest in a shorter period of time. The boy completed the Rapid automatized naming (RAN) test in a shorter period of time but made the same number of mistakes.

H3: After the seven-month speech-language intervention the child scored a higher number of points in the phonological memory subtest. The boy scored almost the maximum number of points thanks to major adjustment to pronunciation.

Research question No. 2: "What changes were observed in the child after the seven-month speech-language intervention in lexical and grammatical subtests?"

H4: After the seven-month speech-language intervention the child scored a higher number of points in the vocabulary subtest. The boy's vocabulary expanded but he did not achieve the maximum number of points.

H5: After the seven-month speech-language intervention the child scored a higher number of points in the implicit grammar knowledge subtest. In Understanding of grammar in the first testing, the boy's achievement was 50\%. After the intervention he scored the maximum number of points. However, the Morphology test showed some persistent mistakes in the use of word forms and active production. In the repeated testing the greatest problems were observed in making plurals and prepositional phrases with a specific case. On the other hand, the maximum number of points was achieved in the block focusing on deriving a verb from in the present tense from the infinitive and in gender inflection of professions. A significant improvement was observed in making the past tense where the boy made almost no mistakes.

H6: After the seven-month speech-language intervention the child scored a higher number of points in the metalanguage grammar knowledge subtest. In tasks aimed at metalanguage skills, which are part of Assessment of grammatical correctness, in the first testing the boy's achievement was $50 \%$. The result suggested a random nature of the responses but after the seven-month intervention the boy scored the maximum number of points. The results of the correcting sentences subtest, which assesses the application of metalanguage knowledge, indicate continuing difficulties. The current language level of the child (intermediate language) is approaching correct grammatical structures. 


\section{Discussion}

The assessment of the boy's language development suggests positive changes in all subtests of the diagnostic battery. However, compared with other Czech children, the communication skills of the bilingual boy are still low. In some subtests he achieves the maximum number of points, while in others the 7-year-old boy does not match the standard of 5-year-olds. In addition to the boy's improvement in the subtests, improvement was also observed in his attention during the test. Compared with the first testing the boy was able to keep his attention for a longer period of time. His responses were quicker, and he attempted to resolve all items. He even said that some of the tasks in the test battery were easy.

Although the diagnostic battery does not include subtests focusing on the pragmatic level of language, the we believe that the boy improved also in this area. The boy is more eager to speak and as a result fulfils his communication intent more often. In spontaneous communication he tends to wait for questions but is gradually gaining confidence.

The mistakes made in the diagnostic subtests were caused by language interference. We assume that the symptoms that resemble specific language impairment are caused by successive bilingualism. The boy made specific mistakes traditionally made by Vietnamese people who learn Czech. The boy's pronunciation was accompanied by elimination, substitution, and metathesis of sounds. Also, a decreased sensitivity to sound quantity was observed. In grammatical tasks the boy made mistakes due to the nature of the Vietnamese language, where words gain grammatical properties based on the context of the sentence.

Regarding the fact that the boy uses the North Vietnamese dialect, mistakes were made especially in the phonological subtests as the consonant inventory of this dialect does not have for example [č] and the sounds [n] and [1] are often confused.

Currently, the boy's pronunciation is approaching the Czech codified standard. Concerning the growing vocabulary, the boy is able to produce more sentences. Improvement was observed in phonological processing in terms of explicit and implicit skills, which are closely related to the initial development of reading and writing. The boy is able to recognize grammatically incorrect sentences but problems with grammar persist in verbal production. The boy is able to conjugate correctly but he continues to struggle with making plurals and declension. According to the author, the full number of points in gender inflection was achieved also due to the boy's long-term memory. As part of the intervention, several activities were included on naming professions. It is interesting to note that after the longterm intervention, the boy maintained the quantity of sounds in the repetition of pseudo-words test (sensitive to specific language impairment in bilingual children) but still made mistakes in sound quantity in the Blending of syllables subtest. 


\section{Conclusion}

The seven-month speech-language intervention supported the development of the boy's communication skills. To support the different language levels, various games and activities were used that involved multiple senses. Emphasis was placed on the development of auditory differentiation (including vowel quantity), auditory memory and phonological awareness (division of words into syllables, analysis and synthesis of sounds, etc.) At the beginning, D. B. Elkonin's language skills training was used for the development of phonemic hearing, which can also be applied in children with a different mother tongue. Although the training of phonemic hearing also affects the person's language skills in other language levels, we believed it was necessary to include more activities in the intervention in order to support the weakened morphological-syntactic level. The intervention also used implicit modelling which, contrary to explicit correction, did not directly point to the incorrect use of language forms. The number of children with a lower level of language skills in the majority language in European countries is increasing. This trend places greater professional demands on speech-language therapists, teachers and other professionals. The objective of the present master's diploma thesis was to analyse the development of communication skills of a successively bilingual Vietnamese child and emphasise some of the specifics resulting from the adoption of the Czech language. The second objective was to examine the conditions in the boy's kindergarten and preparatory class that could have affected his language development.

Language support for children with a different mother tongue should not be underestimated as it is crucial to their successful school attendance. This issue should also be considered by kindergarten administrators who should provide for continuing teacher education in this area. Parents of children with a different mother tongue are not proficient in Czech and are not good language models for their children. The kindergarten is therefore the place where children with a different mother tongue should have the opportunity to adopt the majority language in the most natural way in different contexts and situations.

Speech-language therapists should be aware of the issue of adoption of a second language and adequate language support. Speech-language therapists should provide teachers with recommendations on steps to be taken if they have a foreign language child in their class in order to support the development of their communication skills. 


\section{Acknowledgements}

The article is based on the main author's dissertation and it is partially supported by specific research study IGA_PdF_2020_036 "Research of verbal and nonverbal communication, voice, speech in the context of modern speech - language assessment and therapy" (Principal researcher: Prof. Kateřina Vitásková, Ph.D.) conducted at the Faculty of Education, Palacký University in Olomouc. There is no presumption of conflict of interest in this study.

\section{References}

Atherton, M., Davidson, B., \& McAllister, L. (2019). Growing a profession: Clinician perspectives on the evolving practice of speech-language pathology in Vietnam. http://doi.org/10.6084/ m9.figshare.7634732.v1.

GuU rová, N. (2011). Čeština jako cizí jazyk pro začínající školáky: metodika pro učitele. Praha: Portál.

HÁj KOvÁ, E. (2015). Jazyková výchova dětí sodlišným mateřským jazykem v české mateřské škole. Praha: Univerzita Karlova, Pedagogická fakulta.

Kapalková, S., \& Palugyayová, L. (2016). Narušená komunikačná schopnost’ v multilingválnej spoločnosti. In: A. KeRE KRÉTIOVÁ (ed.), Logopédia (45-50). Bratislava: Univerzita Komenského.

KAPA LKovÁ, S., \& TokÁRovÁ, O. (2019). Schopnost' opakovania pseudoslov jako doplnok informácie o rodinnej anamnéze dietata. Listy klinické logopedie, 1(1), pp. 56-60. https://casopis.aklcr. $\mathrm{cz} /$ archive.php?filtered $=1 \& \operatorname{mag}=1 \mathrm{kl}$ \&year $=2017$ [access: 5.05. 2020].

Kocourek, J., \& Pechová, E (2010). Metodické poznámky k výuce češtiny pro Vietnamce. Praha: Klub Hanoi. https://www.inkluzivniskola.cz/sites/default/files/uploaded/metodicke_poznam ky_k_vyuce_cj_pro_vietnamce.pdf [access: 5.11.2020].

Komers, P., \& Slezá kovÁ, J. (2010). Čeští Vietnamci mezi dvěma jazyky. Vesmír, 89(4), pp. 250 252. https://vesmir.cz/cz/casopis/archiv-casopisu/2010/cislo-4/cesti-vietnamci-mezi-dvema-jazy ky.html [access: 5.04.2020].

Lech ta, V. (2007). Dějiny logopedie ve světovém, evropském a domácím kontextu. In: E. ŠKodová, \& I. Jedličk a (eds.), Klinická logopedie (pp. 29-35). Praha: Portál.

Linhartová, T., \& Loudová Straczynská, B. (2018). Děti sodlišným mateřským jazykem $v$ mateřských školách. Praha: Meta - Společnost pro př́ležitosti mladých migrantů.

PAUL, R., \& Nor BURY, C. (2012). Language disorders from infancy through adolescence. Listening, speaking, reading, writing, and communicating. London: Elsevier.

Ph A M, B., \& MCLEOD, S. (2016). Consonants, vowels and tones across Vietnamese dialects. International Journal of Speech-Language Pathology, 18(2), 122-134. http://www.doi.org/10.3109/1754 9507.2015.1101162.

PhAM, B., \& MCLEOD, S. (2019). Vietnamese-speaking children's acquisition of consonants, semivowels, vowels, and tones in Northern Viet Nam. Journal of speech, language, and hearing research: JSLHR, 62(8), pp. 2645-2670. https://doi.org/10.1044/2019_JSLHR-S-17-0405.

Pham, G., Dinh, K.T., Dam, Q., \& EвеRT, K.D. (2018). Nonword repetition stimuli for Vietnamese-speaking children. Behavior Research Methods, 50(4), pp. 1311-1326. http://doi.org/10.3758/ s13428-018-1049-0. 
Seidlová Málková, G., \& Smolík, F. (2014). Diagnostika jazykového vývoje: diagnostická baterie pro posouzení vývoje jazykových znalostí a dovedností dětí předškolního věku: testová príručka. Praha: Grada. Psyché.

Slavická, N.T.B. (2008). Praktická fonetika vietnamštiny. Praha: Karolinum.

SLówik, O., \& Tůmová, M. (2016). Percepce vietnamské češtiny. Nová čeština doma a ve světě, (pp.15-30). Praha: Univerzita Karlova, Filozofická fakulta 2. http://sea-l.cz/media/1098/vietnamska cestina.pdf [access: 5.4.2020].

ŠT FÁNIK, J. (2010). Bilingvismus. In: V. LeCHTA (ed.), Základy inkluzivní pedagogiky: dítě s postižením, narušením a ohrožením ve škola. Praha: Portál.

TEOFilová, T. (2020). Vývoj komunikační schopnosti bilingvního dítěte v předškolním věku z logopedického hlediska. [Diploma thesis, Mgr.; Supervisor: J. Mironova Tав всноvá]. Olomouc: Univerzita Palackého v Olomouci, Pedagogická fakulta.

Titěrová, K., et al. (2019). Průvodce pro poradny při práci s dětmi a žákys OMJ. http:// https://www. inkluzivniskola.cz/pruvodce-pro-poradny-pri-praci-s-detmi-zaky-s-omj [access: 12.05.2020].

Vasiljev, I. (2010). Vietnamština - jazyk na protipólu. Praha: Muzeum hlavního města Prahy.

Vitásková, K. (2010). Multikulturní prostředí. In: V. LeCH TA (ed), Základy inkluzivní pedagogiky: dítě s postižením, narušením a ohrožením ve škola (pp. 400-416). Praha: Portál.

Vıт ÁsкovÁ, K. (2016). Interkulturalismus - od multikulturality k plurikulturnímu pedagogickému př́stupu. In: V. Lecht A (ed.), Inkluzivní pedagogika (pp. 419-436). Praha: Portál. 